\title{
Az e-learning megaszolgáltatói meg a kutatás
}

Így hivatkozzon erre a cikkre:

Benda Klára. „Az e-learning megaszolgáltatói meg a kutatás”.

Információs Társadalom VIII, 3. szám (2008): 148-156.

A folyóiratban közölt müvek

a Creative Commons Nevezd meg! - Ne add el! - Így add tovább! 4.0

Nemzetközi Licenc feltételeinek megfelelöen használhatók. 
Benda Klára

\section{Az e-learning megaszolgáltatói meg a kutatás}

(Az Analyses of European Megaproviders of E-learning címú kutatási összefoglalóról)

Az európai e-learning szolgáltatókat elemzô könyv egy négy kötetból álló kutatási jelentés utolsó része. Az e-learning szolgáltatások megatrendjeivel foglalkozó kutatás az Európai Unió Leonardo da Vinci-programjának keretében készült hét oktatási intézmény részvételével. A kutatásban a jelenleg Budapesten múködô, angliai székhelyú Európai Távoktatási és E-learning Hálózat (EDEN) és a Budapesti Múszaki és Gazdaságtudományi Egyetem is részt vett.

A kutatás alapötletét egy norvég kutató két korábbi elemzése adta. Paulsen felfigyelt arra a jelenségre, hogy az online oktatási kezdeményezések jelentốs része az indulás után néhány évvel megszúnik, és a nyilvánosan hozzáférhetô információk alapján több ilyen kezdeményezésnél megpróbálta összegyújteni azokat a tényezóket, amelyek hozzájárulhattak a megszúnésükhöz (2003a). Elemzése csak töredékes eredményeket hozott, mert - mint a norvég kutató megjegyzi - az oktatásban nehéz az elkövetett hibákból tanulni, a megszúnő intézmények magukkal viszik azt a tudást is, amelyet saját sikertelen múködésükrôl halmoztak fel. A megszúnés után a dokumentáció, a kulcsszereplók nehezen elérhetók, így a kudarcok okairól sem születnek kutatások és elemzések. Paulsen szerint ez azért is különösen aggályos, mert az ilyen kezdeményezések többsége közpénzeket használ fel.

Egy másik elemzésében Paulsen a kudarcok helyett a siker felól közelítve a témához, azt a kérdést tette fel, hogy milyen tényezók szükségesek egy online oktatási kezdeményezés fennmaradásához (2003b). A siker tényezóit az e-learning jelenlegi helyzetére olyannyira jellemzố oktatási kísérletektól és projektektól elrugaszkodva, a szolgáltató intézmény szintjén igyekezett megragadni. Amikor saját intézményéról, az online távoktatással foglalkozó norvég NKI-ról készített elemzést, nemcsak az ismerős terep vezette az intézmény kiválasztásában, hanem egy széles körú és fenntartható online oktatást nyújtó „megaszolgáltató” profilját igyekezett bemutatni.

Paulsen problémafelvetése számos szempontból gyökeresen különbözik azoktól a megközelítésektól, amelyek az e-learning világát jelenleg uralják:

- A különleges helyett a hétköznapira irányítja a figyelmet, az ígéretek helyett a hosszú távú stabil múködés bizonyítékaira kíváncsi.

- Tematizálja a siker és a kudarc problémáját és az elóbbi kapcsán a fenntarthatóságot.

- Nem a technológia vagy a tartalom, hanem az intézmények sajátosságai felól közelít.

Az e-learning szolgáltatások megatrendjeivel foglalkozó kutatás bevallottan Paulsen kezdeményezését viszi tovább, és az általa megfogalmazott célokat bontja ki. A kutatás jelentốs része a sikeres szolgáltatókkal foglalkozik. Mindenekelốtt azt túzte ki feladatául, hogy olyan európai megaszolgáltatókat találjon, akik széles körü és stabilan fennálló, 
azaz fenntartható e-learning szolgáltatást nyújtanak. A sikeres szolgáltatókkal kapcsolatban a kutatók egyrészt arra voltak kíváncsiak, hogy azok honnan indultak, és hogyan nốtték ki magukat, másrészt pedig a fenntartható e-learning szolgáltatás elemeinek azonosítását tû́zték ki célul.

A kutatás kiterjedt a megszúnt e-learning kezdeményezésekre is. A cél az volt, hogy néhány szolgáltató megszúnésének hátterét a nyilvánosan elérhetố információk alapján feltárják. A kutatást az EU-tagországokban és Norvégiában végezték, és az eredményeket négy angol nyelvú kötetben publikálták, amelyek közül az elsố (The Provision of e-learning in the European Union) országonkénti áttekintéseket tartalmaz az e-learning helyzetéról, a másodikban (Megaproviders of e-learning in Europe) esettanulmányok olvashatók a vizsgált 26 európai e-learning szolgáltató mindegyikéról, a harmadik (E-learning initiatives that did not reach targeted goals) nyolc megszúnt európai és amerikai kezdeményezést mutat be esettanulmányokon keresztül, a negyedik (Analyses of European megaproviders of e-learning) pedig az esettanulmányokban is szereplő szolgáltatók elemzését tartalmazza.

A kutatók - elsôsorban a negyedik kötetben összefoglalt eredmények alapján ajánlásokat is összeállítottak a fenntartható online oktatási szolgáltatások megvalósításához. Az egyes kötetek mellékleteikkel együtt letölthetók a kutatás honlapjáról: www.nettskolen.com/in_english/megatrends

Könyvismertetésem a negyedik kötetról szól, de a kutatás menetének bemutatásánál a többi kötetre is támaszkodtam. Azok számára, akik részletesebben is szeretnének képet kapni az európai e-learning helyzetéról, az esettanulmányokat tartalmazó köteteket is ajánlom. Ezek a kötetek az esettanulmányos forma számos hibáját viselik magukon, de együttesen hasznos áttekintést nyújtanak az online oktatás méltánytalanul elhanyagolt intézményi vonatkozásairól.

Az elemzéseket tartalmazó utolsó kötet kapcsán ugyanakkor komoly fenntartásokat kell megfogalmaznom. A kötetben bemutatott kutatás jó kérdésfelvetését szinte teljesen felülírja a megvalósítást jellemzô módszertani amatörizmus. Az eredmények bemutatása elốtt ezért fontosnak tartom részletesen bemutatni az elvégzett kutatás menetét és az ehhez kapcsolódó fenntartásaimat.

A kutatás megvalósítása négy lépcsóból állt: az intézmények kiválasztása és a kutatási kérdések megfogalmazása után következett az interjús adatgyújtés, majd az interjúk értékelése és elemzése. Az elsô kihívást a vizsgált intézmények kiválasztása jelentette. Ahogy a téma mostoha jellegét illetốn már igyekeztem érzékeltetni, ez a feladat valóban kihívást jelentett, mert nem állt rendelkezésre az európai e-learning megaszolgáltatók listája, tehát először magukat az intézményeket kellett megtalálni. A gyújtést szakmai hálózatok bevonásával, szakmai fórumokra eljuttatott felhívásokkal végezték a projekt portálján keresztül.

A kutatás szempontjából releváns intézményeket az alábbi három kritériummal jellemezték:

1. Online oktatás: a hagyományos oktatásban részt vevő diákok tanulásának online hozzáférhetố tananyagokkal való támogatását nem sorolták az „online oktatás” körébe.

2. Online oktatási intézménynek azokat tekintették, ahol az online programoknak több mint a fele a hálózaton valósult meg. 
3. A jelentôs, fenntartható szolgáltatások körébe azokat sorolták, amelyeket évente legalább 5000 online távoktatási programra beiratkozott tanuló vett igénybe, vagy amelyeknek a kínálatában egyszerre legalább 100 online kurzus szerepelt.

A fenti kritériumok komoly módszertani problémákat vetnek fel. Maguk a kutatók számoltak be arról, hogy a különbözó országokban eltéró modellekben valósul meg az oktatás, az intézmények saját nyilvántartásai alapján lehetetlen a tanulókat egységes kritériumok szerint osztályozni. A jövóbeli kutatások számára hasznos lett volna, ha ezekról a nehézségekról a kutatók részletesen is beszámolnak.

A problémák másik csoportja a számszerúen meghatározott kritériumokhoz kapcsolódik. A tanulmányból nem derül ki, hogy a számokat milyen alapon határozták meg, de a valódi problémát megítélésem szerint nem is ez, inkább a „,beiratkozott tanuló” és a „kurzus” egymással összefüggésben álló fogalmai jelentik. A kutatás az intézmények saját besorolásából indult ki, így egymástól gyökeresen eltérố kurzusok és a hozzájuk rendelt tanulók összeszámolása alapján választották ki az intézményeket. A beiratkozott tanulók létszámát tekintve nem foglalkoztak a lemorzsolódás kérdésével.

Nem derül ki egyértelmúen az sem, hogy a kutatóknak milyen mértékben volt lehetốségük az intézmények által szolgáltatott adatok ellenôrzésére. Öt javasolt intézményt a megadott kritériumok alapján nem vettek fel a megaszolgáltatók közé, négy további intézmény esetében pedig azok rövid távú fennállása, illetve az adatok bizonytalansága miatt fogalmaztak meg fenntartásokat.

A kutatás során végül 25 intézményt vizsgáltak, és a jelentés azt is hangsúlyozza, hogy az egyébként valóban alapos elókészítés ellenére jelentôs szolgáltatók kimaradhattak, ezért a megaproviderek ,jelölésére” a honlapon továbbra is lehetőség van. Az intézmények között tizenkét „egyetemet és fóiskolát”, nyolc „távoktatási intézményt” és öt úgynevezett „oktatócéget” különböztettek meg. Hat szolgáltató szerepel NagyBritanniából, öt Spanyolországból és négy Norvégiából. Kimaradt több északi ország, ahol a távoktatásnak jelentôs hagyományai vannak (Svédország, Finnország és Dánia), valamint Luxemburg, Ausztria és Írország. Magyarország és Észtország kivételével nem szerepelnek a listában az EU újabb tagállamai sem.

A kiválasztás kapcsán felvethetố a reprezentativitás kérdése, ennél azonban komolyabb problémát jelent, hogy az elemzésból, de az esettanulmányokból sem derül ki egyértelmúen, milyen online oktatási tevékenységeket végeznek azok a szolgáltatók, amelyek fenntarthatóságát vizsgálták. Nem egyértelmú pl., hogy szerepelnek-e a kutatásban olyan szolgáltatók, amelyek nem adnak tutori támogatást a kurzusaik elvégzéséhez, s így valójában szinte csak online tartalomszolgáltatóként múködnek.

A kutatás elókészítéséhez tartozott a kutatási kérdések megfogalmazása. A kutatók Paulsennek az NKI-ról készített elemzése alapján hipotéziseket fogalmaztak meg a fenntartható e-learning szolgáltatásokat nyújtó intézmények jellemzóire vonatkozóan. A 25 hipotézis között szerepelt pl. az, hogy az intézmény szabványos és széles körben elterjedt technológiákat használ, a kurzusok költséghatékonyak, és az online oktatás a felsố vezetés támogatását élvezi. A hipotézisekben megfogalmazott pozitív állításokat semlegességre törekvő interjúkérdésekre fordították le. Az intézményekben interjúkat készítettek, ezeket leírták, és a kérdésekre adott válaszokat kódolták. A kódoláshoz egy ötfokú skálát használtak, mintegy „osztályozva” az adott helyeken zajló tevékenységet abból a szempontból, hogy mennyire felelt meg a hipotézisben megfogalmazottaknak, 
illetve mennyire járult hozzá a sikerhez. A kódolást három független kódoló végezte, s a három osztályzat átlaga került be az adatbázisba.

A tanulmány nagy részét az egyes kérdések, illetve hipotézisek kapcsán elért intézményi átlagok bemutatása és elemzése teszi ki. A hipotéziseket tematikus csoportonként más-más szerzók értékelik, így az értékelés formája is változik: míg az átlagok áttekintése és szöveges bemutatása minden téma kapcsán kötelezô elem, van, aki intézményenként hosszabban idéz az interjúkból, mások csak egy-egy fontos részletet emelnek ki. A fontosabb eredmények összefoglalása előtt a fenti módszerrel kapott eredmények áttekintését szeretném bemutatni, elókészítve a módszert illető kritikai megjegyzéseimet.

Az osztályzatok alapján a norvég NKI áll az elsố helyen (átlaga 4,8), ami nem meglepó, ha belegondolunk, hogy a kutatás kiinduló kérdéseit az NKI tevékenysége alapján, az NKI vezetố szakértốje által készített listából állították össze. A felsorolt hipotézisekkel kapcsolatban felmerülő elsố probléma éppen az, hogy egyetlen intézmény tapasztalataira támaszkodnak, ennek külsố adottságait és oktatási modelljét tükrözik.

Az összes szempont és az összes intézmény együttes átlaga 3,8. Az egyetemek átlaga a másik két intézménytípusénál alacsonyabb, de a különbség nem jelentôs. A legjellemzóbbnek a bevett technológiák használata bizonyult (átlaga 4,8), és két szempont kivételével mindegyik 3-asnál jobb átlageredménnyel „végzett”. A 3-as átlag volt az a küszöbérték, amelynek elérése esetén a hipotézis megerósíttetett, és a kutatók az adott tényezốt a „fenntartható e-learning” feltételeihez sorolták.

A hipotézisek elfogadásához valójában a tényezók jelenlétének regisztrálásánál többre lett volna szükség. Hiányzik egyrészt a sikertelen intézményekkel való összehasonlítás, amelynek alapján olyan állításokat lehetne megkockáztatni, hogy egyes tényezốk elmaradása - akár egyenként, akár együttesen - hátráltatja a szolgáltatás fennmaradását. Másrészt hiányzik az egyéb oktatási formákkal, illetve nem oktatási célú online szolgáltatásokkal való összehasonlítás, ami lehetôvé tenné az online oktatásra jellemző speciális sikerkritériumok meghatározását.

A kutatásból leszûrt megállapítások bemutatása elốtt az interjúk lebonyolítása kapcsán felmerülő problémákról kell szólni. Az interjúkat nagyon különbözố szereplókkel készítették, akik között vezetốk, szervezốk és technikai munkatársak egyaránt voltak, és a kutatók visszajelzése alapján ez nem csupán egy-egy terület kidolgozottságában jelentett különbségeket: a megkérdezettek perspektívája sokszor érezhetóen meghatározta a válaszokat. Az összehasonlítást nehezíti, hogy a különbözố intézményekben nem ugyanazt értették a kérdéseken. Az elemzésekból az is kiderül, hogy a beszélgetések mögöttes, átfogó szempontokat hoztak felszínre, amelyek árnyalják vagy keretbe foglalják a javasolt hipotéziseket. A kurzusok kialakítása kapcsán megfogalmazott hipotéziseknél például az derül ki, hogy nem önmagában a tananyagok kialakítása a siker titka, hanem az elvárásokhoz való alkalmazkodás.

A kutatással szemben megfogalmazott fenntartások miatt az eredményeket nem tekinthetjük tudományos értelemben megalapozottnak és hitelesnek, az elemzések mégis tartalmaznak érdekes szempontokat. Az ismertetés utolsó részében ezeket foglalom össze.

Az előzményeket illetôen az interjúk során azt kérdezték meg az intézmények képviselőitól, hogyan fejlődött az online oktatás alapjául szolgáló kompetencia, meny- 
nyire volt ez a fejlődés fokozatos, és milyen szerepe volt a kutatásnak az online oktatás fejlődésében. Az online kompetenciák fejlốdése néhány kivételtól eltekintve minden intézménynél fokozatos volt, a többségnél nem került sor jelentôsebb központi beavatkozásra sem a fejlődés gyorsítása érdekében. A fejlődés mikéntje azonban nagyon sokféle: van, ahol önálló központot hoztak létre, és van, ahol néhány elhivatott szakértố állt a folyamatok mögött. A „kutatáson” szinte kivétel nélkül a minőségfejlesztést értették a válaszolók.

Az előzmények közül nem került be a fontos szempontok közé a távoktatási múlt, ami egyes egyetemek és oktatócégek esetében teljes mértékben hiányzott, míg a távoktatási profillal jellemzett intézmények mindegyikére jellemzố volt, bár itt sem azonos mértékben. A vizsgált intézmények közül az 1914-ben alapított norvég NKS tekinthetố a távoktatás rangidősének, de nagy múltúnak számít a norvég NKI (1959) és a brit Open University (1969) is. Az egyetemek és oktatócégek távoktatási tevékenysége ennél jóval rövidebb múltra tekint vissza, jellemzóen a 90-es években vagy az ezredforduló után indult el.

Az alkalmazott technológiai megoldások tekintetében az intézményeknek a saját IKT-kompetenciáik szintjéról, a felhasználók részéról szükséges szoftverek és hardverek jellegéról, az e-learning rendszerek integrációjáról, valamint az adminisztrációhoz használt rendszerekról kellett nyilatkozniuk.

Az IKT-kompetenciák terén az egyetemek határozottan lemaradnak a távoktatási intézmények és az oktatási cégek mögött, ugyanakkor szembeötlóek a léptékbeli különbségek is: egyaránt „,jeles” értékelést kapott a LearnDirect, melynek száz alkalmazottja foglalkozik a technológiai támogatással és a tananyagfejlesztéssel, és a Magyar Telekom, ahol mindössze egytucatnyi ember végzi ezeket a tevékenységeket. Általánosnak mondható a professzionalizálódás és a feladat iránt elkötelezett támogatói háttér megléte, de olyan intézmény is akadt, ahol az alapfokú felhasználói képességek széles körú elterjedtségét emelték ki.

Az intézmények egy része konkrét technológiákat is megnevezett. Itt az LMS rendszerek között nagyjából azonos aránnyal vannak jelen a saját fejlesztésú, a nyílt forráskódú és a megvásárolt rendszerek. A kérdés kapcsán a tartalmak újrafelhasználhatóságát támogató SCORM-szabvány alkalmazását csak két intézmény említette, a felhasználók számára hozzáférhetố technológiák alkalmazására viszont mindenki nagy hangsúlyt fektet. Ennek mikéntje megintcsak változatos: van, ahol a széles sávot mint elérhetố technológiát emelik ki, míg máshol a széles sáv felhasználói korlátként jelenik meg, és sok helyen az internet mellett a CD is ott van a tananyagok terjesztési formái között. A brit LearnDirect volt az egyetlen, amely a hozzáférés kapcsán saját közösségi hozzáférési pontjainak országos hálózatát hangsúlyozta.

A különbözố rendszerek integrációját tekintve szintén vegyes a kép: az integráció jelentôségét mindenki elismeri, de sokan hiányosságokról is beszámolnak ezen a téren. Az adminisztráció mindenekelốtt mint integrációs probléma jelentkezik.

A harmadik blokkban a kurzuskínálatról, a tantárgyak intézményen belüli jelentôségéról és online tanulhatóságáról nyilatkoztak az intézmények, és a tanár-diák kommunikációt is jellemezték.

A kutatók elófeltevése az volt, hogy a siker fontos tényezóje a változatos kurzuskínálat, a kurzusok kiválasztásánál pedig az online tanulhatóság szempontja, az eredmé- 
nyek azonban egyik feltevést sem erôsítették meg teljes mértékben. A tanulható tantárgyak változatossága nem bizonyult egyöntetúen fontosnak, olyan intézmények is vannak, amelyek eredendóen csak egy-egy részterületet fednek le kurzusaikkal. Az online tanulhatóság is háttérbe szorul a piaci és felhasználói igények és a népszerúség mögött. A témák között a technológiai, gazdasági, társadalomtudományi és egészségügyi területek vezetnek.

A tanár-diák kommunikációban az intézmények a várakozásnak megfelelóen az aszinkron kommunikációs formát hangsúlyozták, de másodlagos csatornaként gyakran megjelent a valós idejư kommunikáció is.

Ebben a blokkban kapott eredetileg helyet a tanulás ütemezésére vonatkozó kérdés is, amely végül kiesett a szempontok közül, mert csak az oktatási cégeknél tartották fontosnak. A másik két intézményi csoportban a központilag meghatározott ütemezést elsôsorban az átfogó intézményi keretek (a szemeszterek, vizsgaidôszakok átfogó rendje, valamint a személyes találkozások, a csoportmunka lehetôségei) indokolják.

A kurzuskínálat kapcsán az elemzés rendhagyó módon kitér a sikertelen kezdeményezésekkel való összehasonlításra is. Úgy tưnik, hogy a sikeres és sikertelen kezdeményezések közötti különbségek nem is annyira a kurzusok tartalmában, változatosságában keresendók, hanem inkább a kereslethez való alkalmazkodás módjában mutatkoznak. A hét vizsgált sikertelen kezdeményezés egy része „kurzusbrókerként” múködött, tehát vagy más intézmények számára kínált kurzusokat (ilyen volt a Kaliforniai Virtuális Egyetem és a norvég IT Fornebu Knowation), vagy külső forrásból származó kurzusok értékesítéséhez kínált platformot (mint például a magyar $S W I$ portálja). Más intézményeknél az jelentett problémát, hogy a végbizonyítványt nem az oktatást ténylegesen nyújtó intézmény biztosította (a brit E-egyetem csak az online oktatást valósította meg az intézményen belül, az Open University amerikai leányvállalata számára pedig az anyaintézmény nyújtotta az oktatást). A sikeres kezdeményezések jellemzóen saját diplomáikhoz tartozó kurzusokat kínálnak, és intézményen belül, az oktatás szempontjainak figyelembevételével valósul meg a kínálat kialakítása és a tartalomfejlesztés. Az Oxfordi, a Stanford és a Yale Egyetemet tömörítô Alliance for Lifelong Learning volt az egyetlen a sikertelen kezdeményezések között, ahol intézményen belül adott volt minden fontos tényezó a keresletérzékeny kurzuskínálat megvalósulásához, de elmaradt a tényleges kereslet jellegének alapos felmérése. Az intézmény az edutainment, a „szórakoztató tanulás” iránti széles körú igény feltételezéséból indult ki, ami azonban tévedésnek bizonyult.

A sikertelen kezdeményezéseknél a piac elôzetes felmérése vagy a kereslethez való alkalmazkodás folyamatainak átgondolt kialakítása maradt el. A szerzó ennek kapcsán találóan mutat rá, hogy a sikertelenek mintha abból az elófeltevésból indultak volna ki, hogy az IK'T-eszközök használata önmagában értéket képvisel a piacon.

Az összehasonlítás alapján tehát úgy túnik, hogy azok a kezdeményezések lesznek sikertelenek, ahol a valós piaci igények nem fogalmazódnak meg világos célok formájában, a tananyagfejlesztésben nem érvényesülnek a pedagógiai és a felhasználói szempontok, illetve az akkreditáció nincs megalapozva, például az oktatás tartalma és a diploma nincs teljes átfedésben. Ezzel szemben inkább számíthatnak sikerre azok a kezdeményezések, amelyek nagy gondot fordítana a piaci igények megisme- 
résére és kielégítésére, valamint a folyamatos önértékelésre, a kurzuskínálat kialakítása során saját intézményi adottságaikra és forrásaikra építenek, és saját diplomát nyújtanak.

A szervezeti kérdéseket érintố kérdésblokkban az alábbi sikertényezók szerepeltek: felsốvezetối támogatás, lelkes alkalmazottak (az ellenállás hiánya), széles körben támogatott online oktatási stratégiák, a minôség kiemelt szerepe, hatékony adminisztráció, kiszámítható és vállalható tanári munkaterhek, együttmúködés más oktatási intézményekkel, az intézmény hitele az önkormányzat és a közigazgatás elốtt, a tömegoktatás munkafolyamatainak megszervezése.

A válaszokban a vezetés támogatása egy-két kivételtól eltekintve mindenhol kiemelten fontos tényezóként jelent meg. Kivételt két egyetem jelent, ahol a támogatásnak nem volt nagy szerepe. A vezetés problémaköréhez kapcsolódik a stratégia, amely összességében fontosnak bizonyult, de részleteiben már nem feltétlenül ismerték, és így megítélése is változatos. Az alkalmazottak hozzáállása szintén vegyes képet mutat, és az elemzés szerint az ellenállás gyakran a vezetés hiányosságait jelzi. A megismert ,jó gyakorlatok", illetve problémák alapján a szerzốk az alábbi megoldásokat javasolják: a technológiával szemben támasztott elvárások tisztázása és a túlzott várakozások eloszlatása; egyértelmú feladatmeghatározás más intézmények példája alapján, rugalmas vagy részmunkaidős munkavégzés, a többletterhelés elismerése; az intézmény belsô kompetenciáinak objektív felmérése. Az utóbbi kapcsán a szerzók a digitális technológiák iránt nyitott fiatal munkatársak bevonását tartják célszerúnek.

Az adminisztráció hatékonysága különböző mértékben, de fontos minden intézménynél, a válaszadók azonban gyakran egészen eltérô elvárásokkal közelítettek a hatékonyság problémájához. Az elvárások között megjelent az adminisztrációs terhek csökkenése, rugalmas és felhasználóbarát adminisztrációs rendszer mind a tanárok, mind a tanulók számára, a folyamatok automatizálása, az adminisztrációs személyzet gyors és számon kérhetô reagálásának biztosítása.

A tanári munkaterhek kapcsán az elemzés rámutat a tananyagfejlesztés és a tanítás megkülönböztetésének jelentôségére, és összehasonlítja az egyetemek és a piaci intézmények eltérố megközelítését. Az egyetemeknél a bevett tanítási formák egyértelmúen szabályozottak, az online tanításhoz kapcsolódó tevékenységekról azonban ez már nem mondható el: tisztázatlanok az elvárások, vagy a bevett formák nehezen alkalmazhatók az újfajta feladatokhoz. Az elemzók hozzáteszik ehhez, hogy a felsôoktatási intézményekre eredendő́n nagyobb rugalmasság jellemző, az itt dolgozók sokféle, nagy hozzáadott értéket képviseló tevékenységet végeznek, és elfogadott az egyenetlen terhelés is. A piaci intézmények jellemző́en a tanítás munkaerô-ráfordításának csökkentésére törekszenek, és az online tanári segítség biztosítását rugalmas, de egyértelmúen szabályozott munkaszervezési formákkal oldják meg. Itt is problémát jelent a tanári terhelés mérése: egyes helyeken tanulónként, míg máshol a megválaszolt kérdések vagy a kijavított feladatok alapján fizetnek.

Hasonlóan alakultak az intézmények közötti különbségek a tömegoktatással kapcsolatos válaszok tükrében is. A piaci intézmények tudatosan alkalmazzák a tömegtermelésre jellemzó módszereket (munkamegosztás, racionalizáció, a munkafolyamatok rendszerbe szervezése, automatizálás), az egyetemeknél a fentiek kisebb jelentôségúek. 
A közigazgatással és kormányzattal fenntartott jó viszony a legfontosabb sikertényezốk közé tartozik. Az intézmények általában sok szempontból függenek az államtól, amelynek szerepe lehet az oktatás rendszeres és eseti finanszírozásában, akkreditációjában, illetve felügyeletében, ezért elemi érdekük a jó viszony kialakítása, az intézmény hírnevének megalapozása. Voltak ugyanakkor olyan válaszadók is, akik a kormányzattól való függetlenséget hangsúlyozták. Az intézményi együttmúködés - az eróforrások és a tapasztalatok megosztása - az oktatási cégeknél kiemelten fontos, az egyetemek és távoktatási intézmények körében azonban már kevésbé mondható népszerúnek.

Az utolsó kérdéscsoport az intézmények gazdálkodását járta körbe. Az idetartozó sikertényezók a költséghatékonyság, a kiszámítható jövedelemforrások, a kihívásokból adódó változási kényszer és a rendhagyó alkalmazási formák. Ezek a tényezók általában fontosnak mondhatók, de az intézmények között nagy különbségek vannak. Az alkalmazási formák tekintetében megjelenik az egyetemek már korábban jelzett elkülönülése. A finanszírozási kérdések megítélése jelentôsen változik aszerint, hogy az intézmény milyen mértékben támaszkodhat kormányzati forrásokra. Az egyetemek között olyan is előfordult (az észt Tartui Egyetem), amely kizárólag központi forrásból tartja fenn magát. A piacról élő intézményeknél ugyanakkor a költséghatékonyság és a stabil jövedelem nagyon fontosnak bizonyult. Az alkalmazkodás a nagy múltú távoktatási intézmények esetében tartozik a meghatározó tényezók közé.

A kutatók azt is megkérdezték az intézmények képviselőitốl, milyen további szempontokat tartanak lényegesnek a saját sikerük szempontjából. Míg az intézmények többsége említett ilyen szempontokat, ezek között szinte soha nincs átfedés, így az elemzók arra a következtetésre jutottak, hogy a sikerhez nem vezet „királyi út”, az intézmények a saját helyzetükre érzékeny egyedi megközelítéssel válhatnak sikeressé.

Befejezésül a kutatás kiindulópontjához térnék most vissza. Ahogy igaza van Paulsennek, amikor azt állítja, hogy számos e-learning kezdeményezés kudarcát az a naiv feltételezés okozta, hogy a technológia (oktatási) használata önmagában elég a sikerhez, ugyanúgy erról a kutatási projektról is elmondható, hogy abból a feltételezésból indult ki, hogy a kutatás önmagában elég a sikerhez, és tudományosan megalapozott tudáshoz vezet. Nem gondolom, hogy az esettanulmányok vagy a kutatási eredmények hozzájárulnának a kutatás bevezetôjében megfogalmazott jövốkép megvalósulásához, hogy a jövóben kevesebb átgondolatlan e-learning kezdeményezés valósuljon meg az adófizetốk pénzéból. Az is bizonyosra vehetô, hogy más léptékben, de sok közpénzt fognak még elrontott kutatásokra is elkölteni. Ugyanakkor mégis hasznos lesz ez a négy kötet azon intézmények számára, akik jó online oktatást akarnak megvalósítani, mert a saját problémáikhoz hasonlókkal találkoznak a kötetekben, és megerósítést, szempontokat, kiindulópontokat találhatnak a munkájukhoz. És magát a kutatást is feltétlenül folytatni kell.

Az Analyses of European Megaproviders of E-learning címú kötet szerzói: Per Arneberg, Lourdes Guardia, Desmond Keegan, Jüri Lõssenko, Mázár Ildikó, Pedro Fernández Michels, Morten Flate Paulsen, Torstein Rekkedal, Albert Sangra, Jan Atle Toska, Zarka Dénes. 


\section{Irodalom}

Paulsen, M. F. 2003a. Online Education Obituaries. In Online Education and Learning

Management Systems. Global E-learning in a Scandinavian Perspective, M. F. Paulsen. Bekkestua, NKI Forlaget, 145-150. www.studymentor.com/studymentor/Obituaries.pdf (2008. jún. 19.)

Paulsen, M. F. 2003b. NKI Fjernundervisning: Two Decades of Online Sustainability. In Online Education and Learning Management Systems. Global E-learning in a Scandinavian Perspective, M. F. Paulsen. Bekkestua, NKI Forlaget, 271-292.

www.studymentor.com/studymentor/NKI.pdf (2008. jún. 19.) 